\title{
Effect of Abelmoschus ficulneus (L.) Wight \& Arn. on immunomodulation: in vivo experimental animal models
}

\author{
Neelam Laxman Dashputre ${ }^{1,2^{*}}$ and Deepti D. Bandawane ${ }^{3}$
}

\begin{abstract}
Background: Abelmoschus ficulneus (L.) Wight \& Arn. (Malvaceae) commonly known as herb in the Ayurveda, Indian traditional medicine system. Herb is reported as a Rasayana that has the potential to produce immunomodulatory effects. In the present study, the immunomodulatory effect of aqueous (AEAF) and ethanolic (EEAF) leaves extract of A. ficulneus (L.) Wight \& Arn. in different experimental animal models were evaluated.
\end{abstract}

Results: Acute oral toxicity shows that both extracts have wide range of safety as per OECD 420 guidelines. Quantitative and qualitative analysis was evaluated by performing preliminary phytochemical screening, thin layer chromatography and highperformance thin layer chromatography developed for simultaneous quantification of flavonoids (quercetin) in both the extracts. Oral administration of $A$. ficulneus $L$. extracts showed a significant increase in the primary and secondary humoral antibody responses against cyclophosamide $(100 \mathrm{mg} / \mathrm{kg})$ induced immunosuppression, by significantly increasing $(p<0.05)$ the hemagglutinating antibody titre at dose of $200 \mathrm{mg} / \mathrm{kg} / \mathrm{p}$.o. and also significantly $(p<0.05)$ potentiated delayed type hypersensitivity reaction induced by sheep red blood cells. There was a significant $(p<0.05)$ increase in the phagocytic index, percentage neutrophil adhesion and significantly prevented the mortality induced by bovine Pasteurella multocida in mice when compared with control group. Result findings shows that both the extracts have ability to inhibit immunosuppression induced by cyclophosamide.

Conclusion: Study finding shows that AEAF and EEAF (at dose $200 \mathrm{mg} / \mathrm{kg}$ ) extracts exerts immunostimulatory effects on specific and nonspecific immune system thus chemical constituents of herbal extracts may have applications as an effective immunotherapeutic agent and its potential application in the treatment of immune-related diseases.

Keywords: Immunomodulation, Abelmoschus ficulneus (L.), Haemagglutination titre, Delayed type of hypersensitivity, Phagocytic index and neutrophil adhesion

\section{Background}

Ayurveda is the vital indigenous medicine system of India. Rasayana therapy is one of the eight major divisions of Ayurvedic discipline [1].

Rasayana remedy on human being has been reported by various scientists; the mechanism of action of

\footnotetext{
* Correspondence: neelamdashputre@gmail.com

'Department of Pharmacology, PES's, Modern College of Pharmacy, Affiliated to Savitribai Phule Pune University, Yamunanagar, Nigdi, Pune, Maharashtra 411044, India

2Department of Pharmacology, METs, Institute of Pharmacy, Bhujbal

Knowledge City, Adgaon, Nashik, Maharashtra 422003, India

Full list of author information is available at the end of the article
}

Rasayana remedy have not been scientifically explored much. The modern research has only evidenced the biological activity of the medicinal plants and their active ingredients. Based on the findings, the Rasayana therapy is interpreted in modern science like immunomodulatory action, anti-ageing action, apoptogenic action, endurance or extended life span, etc. [2].

The concept "Vyadhi-ksamatva" is often associated with immunology. Vyadhi means disease or disorders and ksamatva means capacity to defence. Specific class of agents like anti-allergic, corticosteroids, anticancer and chemotherapeutic have been employed to protect against

\section{Springer Open}

( ) The Author(s). 2021 Open Access This article is licensed under a Creative Commons Attribution 4.0 International License, which permits use, sharing, adaptation, distribution and reproduction in any medium or format, as long as you give appropriate credit to the original author(s) and the source, provide a link to the Creative Commons licence, and indicate if changes were made. The images or other third party material in this article are included in the article's Creative Commons licence, unless indicated otherwise in a credit line to the material. If material is not included in the article's Creative Commons licence and your intended use is not permitted by statutory regulation or exceeds the permitted use, you will need to obtain permission directly from the copyright holder. To view a copy of this licence, visit http://creativecommons.org/licenses/by/4.0/. 
immunological extremity and microorganism. However, modern synthetic therapy has many adverse effects. Phyto remedies seem to be significant sources as immunomodulatory agents. Therefore, it seems to be abundant to explore phyto remedies for potential immunomodulatory activity [3]. Recently, a wide number of in vitro studies have suggested a role of flavonoids isolated from plants in the modulation of immune response, through the stimulation of $\mathrm{B}$ and $\mathrm{T}$ cell immune response with respect to immune-mediated disorders $[4,5]$.

The genus Abelmoschus (Family-Malvaceae) is one of the pharmaceutically important groups of the flowering plants. The species A. ficulneus L. has prominent role in the traditional medicinal practices due to the presence of prominent phytochemicals. A. ficulneus $\mathrm{L}$. is an edible medicinal plant has wide range of medicinal applications. The whole plant is used to treat sprain, bronchitis and toothache and Abelmoschus taxa have applications in industry [6].

A. ficulneus L. were found to have a high flavonoid, saponin and phenolic contents, which are responsible for all pharmacological activities including jaundice and a major fatal disease [7].

Therefore, increased in the demand of herbal medicines for therapeutic applications, it has become necessary to exploit the medicinal potential of plant species.

Hence, the present work proposed to evaluate immunomodulatory effect of $A$. ficulneus L. on humoral and cellular immune response by various experimental animals' models: in vivo and in vitro studies.

\section{Methods}

\section{Drugs and chemicals}

Analytical grade solvents (ethanol and petroleum ether), Cyclophosphamide (Alkem Laboratories Ltd. Mumbai), Levamisole (Khandelwal pharma. Ltd. Mumbai), Quercetin (Modern Industries, Sinner), Colloidal carbon (camel India Pvt. Ltd.), Nylon fibres (Local market, Nashik, India). Pasteurella multocida of bovine origin vaccine (Government Veterinary Hospital, Nashik).

\section{Plant procurement and authentication}

A. ficulneus L. herb was collected and procured in the month of July and leaves were dried in the shade. The $A$. ficulneus L. was authenticated by an herbarium section of a botanical survey of India, Maharashtra, Pune. No. BSI/WRC/Cert./2014.

\section{Experimental animals}

For the evaluation of immunomodulatory effect, adult healthy Swiss albino mice (Mus musculus, having 10-12 weeks old, 18-22 g body weight were used in this study, $n=6$ in each group of models) either sex was used and housed at $25 \pm 5{ }^{\circ} \mathrm{C}$ in a ventilated animal house under
12/12 h light/dark cycle. Animals were purchased from LACSMI Bio Farms (Laboratory Animal Centre for Safe Medical Innovations), \# 12, "Rachana Blossom", Jagdishnagar, Aundh, Pune-411 007, Maharashtra CPCSEA Registration Number: 1277/PO/RcBt/S/09. The all mice were maintained under standard conditions in an animal house approved as per the guidelines of CPCSEA, Department of Animal Welfare, and Government of India. All mice were fed with a pelleted diet and distilled water ad libitum. The experimental animal protocol was approved by the Institutional Animal Ethical Committee (IAEC) (Protocol No. 884/PO/Re/S/05/CPCSEA).

\section{Preparation of leaves extracts}

The dried leaves coarse powder (500 g) was extracted by using Soxhlet apparatus by petroleum ether $\left(40-60{ }^{\circ} \mathrm{C}\right)$ to remove resinous and fatty material for $12 \mathrm{~h}$. Then defatted marc was subjected through $95 \%$ ethanol for $24 \mathrm{~h}$ to obtain the ethanolic extract. For aqueous extract dried leaves, coarse powder macerated with chloroform and distilled powder (1:9) for 7 days. The aqueous extract of A. ficulneus L. (AEAF) and ethanolic extracts A. ficulneus L. (EEAF) were evaporated up to $30{ }^{\circ} \mathrm{C}$ temperature to yield a yellowish-brown powder. Both extracts were sealed in an airtight polythene or container and stored at $4{ }^{\circ} \mathrm{C}$ for further experimental work $[8,9]$.

\section{Preliminary phytochemical investigations}

Preliminary phytochemical analysis was carried out to check and identify the effective constituents of leaves extracts $A$. ficulneus L. investigated for as per the standard procedure reported practical pharmacognosy books $[9,10]$.

\section{Total flavonoid content determination}

For estimation of total flavonoid content (TFC), aluminium chloride method was used and quercetin is used as a standard. The TFC was determined from the calibration curve of quercetin and expressed as $\mathrm{mg}$ of $\mathrm{QE} / \mathrm{gm}$ of dry weight. Method was repeated 3 times for precision and values were expressed in mean \pm STD deviation in terms flavonoid content, quercetin equivalent per $g$ of dry weight $[11,12]$.

\section{Total phenol determination}

Folin-Ciocalteu's assay was used to determine total phenol content using gallic acid as a standard. Absorbance of sample was measured with the blank at $750 \mathrm{~nm}$ using a spectrophotometer. Method was repeated three times for precision and values were expressed in mean \pm standard deviation in terms of phenol content, gallic acid equivalent, GAE per $g$ of dry weight [13]. 


\section{Thin layer chromatography}

Active constituents (flavonoids) of A. ficulneus L. leaves extracts were detected by the method thin layer chromatography using silica gel 60 TLC plates. These phytochemicals were identified and compared with their retention time obtained, which is compared with the standard (quercetin) retention time for flavonoids. The volume of the spots applied on the chromatographic plates was $5 \mu \mathrm{l}$ and TLC were performed by ethyl acetate:water:formic acid:glacial acetic acid (100:26:11:11) mobile phase for both extracts. The presence of flavonoid was detected by the formation of yellowish-brown colour on TLC plate by exposure of polyethylene glycol reagent on TLC plate. The chromatograms were evaluated without chemical treatment, under UV 254 and UV $365 \mathrm{~nm}$ light. Rf value was calculated by the formula, distance travelled by the sample and distance travelled by the solvent $[14,15]$.

\section{HPTLC instrumentation and method}

Chromatographic analysis carried out on plate size $10 \times$ $10 \mathrm{~cm}$ HPTLC plates silica gel $60 \mathrm{~F}_{254}$ purchased from E. MERCK KGaA instrument (Germany). Samples of standards and extracts were applied as band length $6.0 \mathrm{~mm}$ wide and $8.0 \mathrm{~mm}$ apart by Camag Linomat 5 sample applicator. The application rate of sample on plate was 150 $\mathrm{nl} / \mathrm{s}$. Analysis was done at $380 \mathrm{~nm}$ in absorbance remission mode by win CATS Chromatography software [16].

\section{Preparation of standard}

A stock solution of quercetin $(100 \mu \mathrm{g} / \mathrm{ml})$ was prepared by dissolving $10 \mathrm{mg}$ of accurately weighed quercetin in $100 \mathrm{ml}$ ethanol. For calibration 5-20 $\mu \mathrm{l}$ standard solution were applied to HPTLC plate in the range 500$2000 \mathrm{ng}$ per band.

\section{Preparation of sample solution}

Extraction of leaves of A. ficulneus L. were carried out by solubility of the marker constituents, ethanolic leaves extract prepared by weighing $50 \mathrm{~g}$ of dried powdered of leaves of A. ficulneus $\mathrm{L}$. and extraction done by maceration method for $24 \mathrm{~h}$. Solution was filtered, concentrated, evaporated through distillation and used for further HPTLC analysis.

\section{Method validation}

The analytical method was validated for specificity, linearity, limit of detection (LOD) and limit of quantization (LOQ) according to the International Council for Harmonization ( $\mathrm{ICH}, 2005)$ guidelines. The specificity calculated by comparing Rf values and ultraviolet-visible (UV) spectra of peaks of components in sample and standard chromatogram.

\section{Acute toxicity study}

The oral acute toxicity study for both the extracts were carried out as per the OECD 420 guidelines in female mice at a single dose of $2000 \mathrm{mg} / \mathrm{kg}$. As per the guidelines, mice were observed for $48 \mathrm{~h}$ for behavioural changes of toxicity and animals kept for 14 days under observation for any toxicological signs and lethal outcome [17].

\section{Evaluation of immunomodulatory effect}

The effect of both extracts (AEAF and EEAF) on immunomodulation the specific and nonspecific immune response was evaluated in mice using in vivo experimental animal models.

\section{Specific immune response: humoral antibody response Antigen: sheep red blood cells}

In the specific immune responses, sheep red blood cells (SRBCs) are used as an antigen. Fresh blood was collected in freshly prepared sterile Alsevere's solution in 1: 1 proportion. Three times sheep blood was washed by centrifugation method at 3000-5000 rpm for $15 \mathrm{~min}$. And after the final wash, red blood cells were suspended in normal saline and makeup final concentration of SRBCs up to $1 \times 10^{9}$ cells and used for immunization and challenge. One millilitre of the $2 \%$ suspension contained approximately $10^{9}$ red blood cells.

\section{Evaluation of humoral antibody response}

For humoral immune response, mice grouped into total eight groups consisting of six mice $(n=6)$ in each group. Group 1 received (negative control) Cyclophosphamide (Cyp.100 mg/kg, p.o.), single-dose on $9^{\text {th }}$ and $16^{\text {th }}$ day; group 2 received (vehicle control ) distilled water (10 $\mathrm{ml} / \mathrm{kg}$, p.o.), for 21 days; group 3 (test extract 1 ) received AEAF (200 mg/kg p.o.) for 21 days; group 4 (test extract 2) received EEAF (200 mg/kg p.o.) for 21 days; group 5 (standard) received Levamisole (LMS $50 \mathrm{mg} / \mathrm{kg}$, p.o.) for 21 days; group 6 received AEAF (200 mg/kg p.o.) for 21 days and a single dose of Cyp.100 mg/kg, p.o. each on $9^{\text {th }}$ and $16^{\text {th }}$ day; group 7 received EEAF $(200 \mathrm{mg} / \mathrm{kg}$ p.o.) for 21 days and Cyp. $100 \mathrm{mg} / \mathrm{kg}$, p.o. single dose each on $9^{\text {th }}$ and $16^{\text {th }}$ day; group 8 received LMS $(50 \mathrm{mg} /$ $\mathrm{kg}$, p.o.) for 21 days and Cyp. $100 \mathrm{mg} / \mathrm{kg}$, p.o. single dose each on $9^{\text {th }}$ and $16^{\text {th }}$ day. Mice from all groups were immunized by $0.1 \mathrm{ml}$ intraperitoneal of suspension $1 \times 10^{9}$ cells SRBCs $/ \mathrm{ml}$ on the $7^{\text {th }}$ and $14^{\text {th }}$ day considered for immunization. Blood samples were collected from all groups of mice by retro-orbital plexus on $14^{\text {th }}$ day of study considered for primary antibody response and also blood samples withdrawn on the $21^{\text {st }}$ day of study considered for secondary antibody response, after immunization. Blood was centrifuged and serum was isolated for determination of antibody levels by the 
Table 1 Total flavonoid content in different A. ficulneus $L$. leaves extracts

\begin{tabular}{ll}
\hline A. ficulneus L. leaves extract & mg of QE/g of dry weight $\mathbf{\pm} \mathbf{S D}$ \\
\hline Aqueous extract & $9.8 \pm 0.7$ \\
Methanolic extract & $27.83 \pm 0.305$ \\
Ethanolic extract & $24.36 \pm 0.91$ \\
Hydroalcoholic extract & $14.06 \pm 0.91$ \\
\hline
\end{tabular}

haemagglutination technique by 96 -wells U-shaped microtiter plates. Two-fold dilutions $(0.025 \mathrm{ml})$ of serum samples were performed in the 96-wells microtiter plates with normal saline. In each well, $0.025 \mathrm{ml}$ of $1 \%(\mathrm{~V} / \mathrm{V})$ SRBCs were added. The plates kept for incubation for 1 $\mathrm{h}$ at room temperature and then evaluated for haemagglutination. The highest dilution set out haemagglutination was considered for antibody titre; titre was expressed in a graded manner and the minimum dilution $(1 / 2)$ being ranked as 1 . The mean ranks of all groups were compared for statistical analysis $[3,18]$.

\section{Cell-mediated immune response: delayed type hypersensitivity reaction}

Cell-mediated immune response was measured using delayed type hypersensitivity (DTH) reaction by foot paw oedema method. Mice were divided into eight groups same as humoral antibody (HA) titre. On the $21^{\text {st }}$ day of the study, all animals from each group were immunized with $0.1 \mathrm{ml}$ of $1 \%$ SRBCs suspension in the sub plantar route of the right-hand paw. After $24 \mathrm{~h}$, animals in all groups were assessed for foot paw oedema reaction, i.e. on the $22^{\text {nd }}$ day. The oedematous thickness of the right footpad injected with SRBCs was determined by the vernier calliper method. The hypersensitivity reaction was expressed as the difference in the thickness $(\mathrm{mm})$ between the right and left footpad injected with normal saline $[3,18,19]$.

\section{Non-specific immune response Neutrophil adhesion test}

Nonspecific immune response was assessed by neutrophil adhesion method. Mice are divided into four groups of six animals in each group. Group 1 control received

Table 2 Absorbance of Quercetin in chelated form at

$\lambda \max =510 \mathrm{~nm}$

\begin{tabular}{ll}
\hline $\begin{array}{l}\text { Concentration of Quercetin } \\
(\boldsymbol{\mu g} / \mathbf{m l})\end{array}$ & $\begin{array}{l}\text { Absorbance at } \\
\lambda \text { max }=\mathbf{5 1 0} \mathbf{~ n m}\end{array}$ \\
\hline 20 & 0.165 \\
40 & 0.315 \\
60 & 0.475 \\
80 & 0.616 \\
100 & 0.757 \\
\hline
\end{tabular}

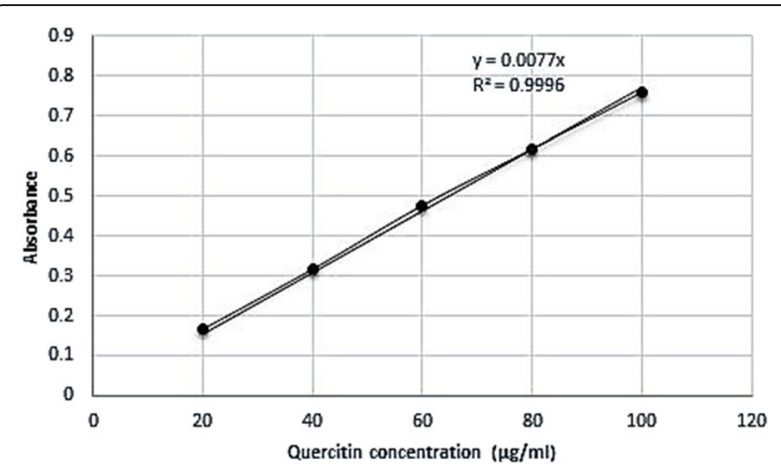

Fig. 1 Calibration curve of quercetin

distilled water, $10 \mathrm{ml} / \mathrm{kg}$, p.o. for 14 days; group 2 and group 3 (test 1 and test 2 respectively) received AEAF $200 \mathrm{mg} / \mathrm{kg}$ and EEAF $200 \mathrm{mg} / \mathrm{kg}$ p.o. for 14 days. Group 4 standard received Levamisole $50 \mathrm{mg} / \mathrm{kg}$ for 14 days. On the $14^{\text {th }}$ day of the study, blood samples were collected in pre-treated EDTA vials from all groups of mice by retro-orbital plexus and analyzed for differential leukocyte count (DLC) and total leucocyte count (TLC). After initial count analysis, all blood samples were incubated in nylon fibres $80 \mathrm{mg}$ nylon fibres/ml for $15 \mathrm{~min}$ at $37{ }^{\circ} \mathrm{C}$ and again blood samples of incubated in nylon fibres were again analyzed for DLC and TLC respectively to give a neutrophil index and adhesion of blood specimens.

The percent of neutrophil adhesion was calculated by given formula:

$$
\begin{aligned}
& \text { NeutrophilIndex }=T L C \times \% \text { Netrophils } \\
& \text { NeutrophilAdhesion }=N I u-N I t \div N I u \times 100
\end{aligned}
$$

Were,

NIu: Neutrophil Index of blood samples

NIt: Neutrophil Index of blood samples incubated with nylon fibres [20].

\section{Carbon clearance test}

Mice were divided into four groups, the same as described in neutrophil adhesion tests. Carbon ink suspension and normal saline used in a 1:8 proportion and

Table 3 Absorbance of Gallic acid equivalent at $\lambda$ max $=750 \mathrm{~nm}$

\begin{tabular}{ll}
\hline $\begin{array}{l}\text { Concentration of Gallic } \\
\text { acid }(\mu \mathbf{g} / \mathrm{ml})\end{array}$ & $\begin{array}{l}\text { Absorbance at } \\
\lambda \max =\mathbf{7 5 0} \mathbf{n m}\end{array}$ \\
\hline 2 & 0.017 \\
4 & 0.032 \\
6 & 0.048 \\
8 & 0.062 \\
10 & 0.075 \\
\hline
\end{tabular}


Table 4 Thin layer chromatography of standard and aqueous and ethanolic extracts

\begin{tabular}{llll}
\hline Phytochemical & Rf value & Result & Literature \\
\hline Aqueous extract: Flavonoid & $2.1 / 3.8$ & 0.55 & Quercetin \\
Ethanolic extract: Flavonoid & $2.9 / 4$ & 0.72 & Quercetin \\
\hline
\end{tabular}

used for test in a dose of $10 \mu \mathrm{l} / \mathrm{g}$ body weight of mice. Carbon ink solution was injected by tail vein route to each mouse $48 \mathrm{~h}$ after the $14^{\text {th }}$ days of treatment, i.e. on the $14^{\text {th }}$ day. Then, $25 \mu \mathrm{l}$ blood samples were collected by retro-orbital plexus at 0 and 15 min after injection carbon ink solution and blood was mixed with $2 \mathrm{ml}$ of $0.1 \%$ sodium carbonate solution. The optical density (OD) of the samples was measured spectrophotometrically at $660 \mathrm{~nm}$. The phagocytic index (K) was calculated by equation: $K=\log O D 1-\log O D 2 / 15$, where $\mathrm{OD}_{1}(0$ min) and $\mathrm{OD}_{2}(15 \mathrm{~min})$ are the optical densities respectively [21].

\section{Mice lethality test}

Mice were divided into five groups of 6 mice in all groups. Control group 1 received no drug, no vaccination; group 2 vehicle/positive control, received distilled water, $10 \mathrm{ml} / \mathrm{kg}$, p.o. and vaccination; groups 3 and 4 received AEAF $200 \mathrm{mg} / \mathrm{kg}$ and EEAF $200 \mathrm{mg} / \mathrm{kg}$, p.o. for 21 days; and group 5 standard Levamisole received 50 $\mathrm{mg} / \mathrm{kg}$ for 21 days. On the $7^{\text {th }}$ and $17^{\text {th }}$ day of an experiment, all groups were immunized through the intraperitoneal route with haemorrhagic septicaemia vaccine $(0.2$ $\mathrm{ml} /$ mouse s.c.), except control group. On the $21^{\text {st }}$ days of an experiment, the mice were challenged with $0.2 \mathrm{ml}$ of $25 \mathrm{ml} \mathrm{LD}_{50}$ dose of Pasteurella multocida (bovine origin) containing $10^{7}$ cells per ml subcutaneously and were examined for about $72 \mathrm{~h}$ and percentage mortality is calculated as [22],

\section{Percent mortality $=($ Number of animal's dead $)$} $/$ Total number of animals $\times 100$.

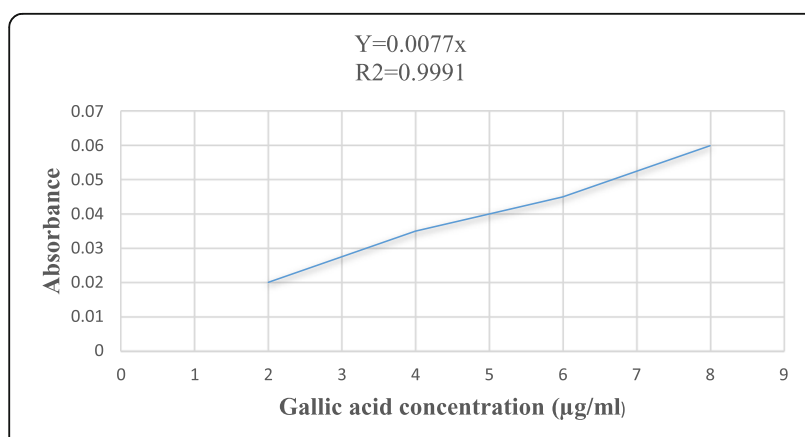

Fig. 2 Standard calibration curve of Gallic acid

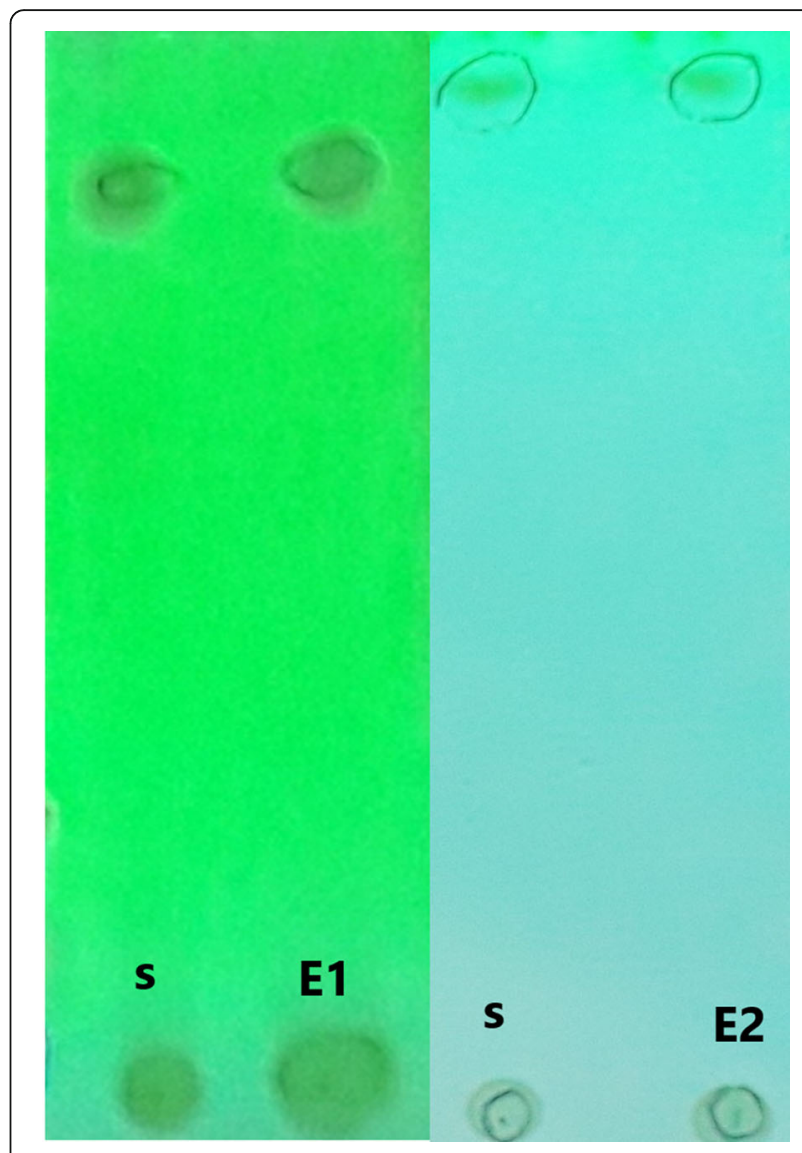

Fig. 3 Thin layer chromatography of standard and aqueous and ethanolic extracts

\section{Method of anaesthesia}

In present work, all animals (Except mice lethality test animals) were anaesthetized by pharmacological method with Pentobarbital sodium $25 \mathrm{mg} / \mathrm{kg}$ i.p. (Mfg by Alcami corp., Charleston, USA.) for post operational studies.

\section{Statistical analysis}

All the investigational data were expressed as mean \pm SEM. The parameters such as humoral immune response and cellular immune response were analysed by one-way ANOVA followed by Tukey-Kramar multiple comparison test. Whereas neutrophil adhesion test, carbon clearance and mice lethality test were analysed by

Table 5 Total phenolic content in different A. ficulneus L. leaves extracts of Gallic acid

\begin{tabular}{ll}
\hline A. ficulneus L. leaves extract & $\begin{array}{l}\text { Total phenolic content } \\
\text { ( } \mathbf{m g} \text { of GAE/g of dry weight) } \mathbf{+} \text { SD }\end{array}$ \\
\hline Aqueous extract & $41.66 \pm 0.288$ \\
Methanolic extract & $48.83 \pm 0.288$ \\
Ethanolic extract & $47.16 \pm 1.25$ \\
Hydroalcoholic extract & $43 \pm 0.5$ \\
\hline
\end{tabular}




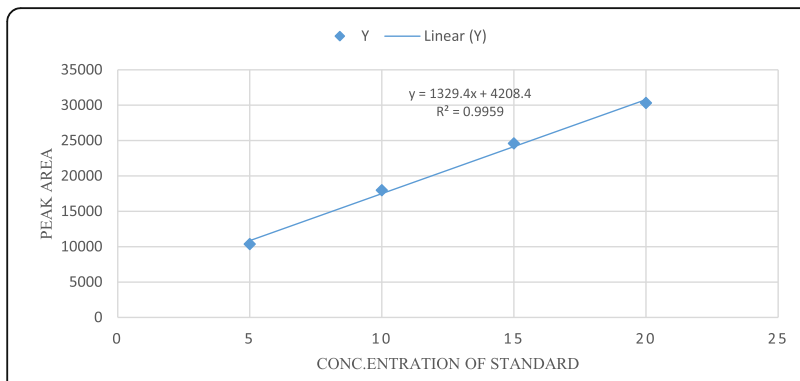

Fig. 4 Calibration curve of standard of quercetin

one-way ANOVA by Dunnett's multiple comparison test using GraphPad Prism trial version 5.01 (GraphPad Software, Inc); $p<0.05$ was considered statistically significant for comparison.

\section{Results}

\section{Preliminary phytochemical evaluation}

The phytochemical screening of leaves extracts of $A$. ficulneus L. showed the presence of glycosides, carbohydrates, fixed oils and fats, proteins and amino acids, saponins, tannins, phytosterols, phenolic compounds alkaloids and flavonoids while gums and mucilage are absent.

\section{Total flavonoid content}

The total flavonoid content for extracts of AEAF and EEAF presented in Table 1 as well as absorbance of standard compound (quercetin) is shown in Table 2 at different concentrations and standard curve of quercetin indicated the equation of $y=0.0077 x$ and $R^{2}=0.9977$ clarified in Fig. 1 (Table 3).

\section{Total phenolic content}

The total phenolic content for different extracts of $A$. ficulneus $\mathrm{L}$. leaves presented in Table 4 as well as absorbance of standard compound (gallic acid) is shown in this Table 5 at different concentrations. Standard curve of gallic acid indicated the equation of $y=0.0077 x$ and $R^{2}=0.9947$ clarified in Fig. 2.

Table 6 Method validation parameters for the quantification of quercetin

\begin{tabular}{ll}
\hline Parameters & Results \\
\hline Range of linearity (ng/band) & $1000-35000$ \\
Regression of equation & $1329.4 x+4708.4$ \\
Slope & 1329.4 \\
Correlation coefficient ( $r 2)$ & 0.9831 \\
LOD (ng/band) & 8.3787 \\
LOQ (ng/band) & 25.39 \\
\hline
\end{tabular}

\section{Thin layer chromatography}

Thin layer chromatogram of aqueous and ethanolic extract was given in Fig. 3 and results are tabulated in Table 4. Based on Rf value, aqueous and ethanolic extract of A. ficulneus L. a spot having 0.72 and 0.76 respectively. This value compared with standard $\mathrm{Rf}$ value of flavonoid and it was identified as flavonoid compound as quercetin in the extract of $A$. ficulneus $\mathrm{L}$.

\section{HPTLC evaluation}

\section{Preparation of calibration curve and linearity}

The standard solutions of quercetin were prepared (100 $\mu \mathrm{g} / \mathrm{ml})$ in methanol. They were diluted to make different concentrations for calibration curves and were applied on TLC plate. The plate was scanned at $380 \mathrm{~nm}$ and curve was plotted with respect to peak area vs. concentration/amount per spot (Fig. 4). A good linearity was found to be with correlation coefficient $\left(r^{2}\right)$ value of 0.9831 for quercetin (Table 6 and Fig. 4).

\section{Limit of detection and limit of quantitation}

Limit of detection (LOD) and limit of quantitation (LOQ) were calculated based on standard deviation (SD) and slope (S) of the calibration curve at levels according to formula $\{\mathrm{LOD}=3.3(\mathrm{SD} / \mathrm{S})$ and $\mathrm{LOQ}=10(\mathrm{SD} / \mathrm{S})\}$. and found to be 8.3787, $25.39 \mathrm{ng}$ for quercetin (Table 6) [23].

\section{Specificity}

The specificity was determined by comparing Rf values and ultraviolet-visible spectra of peaks of components in samples and standard chromatogram. Purity of sample spot corresponding to quercetin in sample was analyzed by overlaying the spectrum of standard and sample peaks (Fig. 5).

Observation shows the Rf values at 0.64 and 0.62 at $380 \mathrm{~nm}$ respectively (Figs. 6 and 7) for quercetin in standard and samples respectively by densitometry.

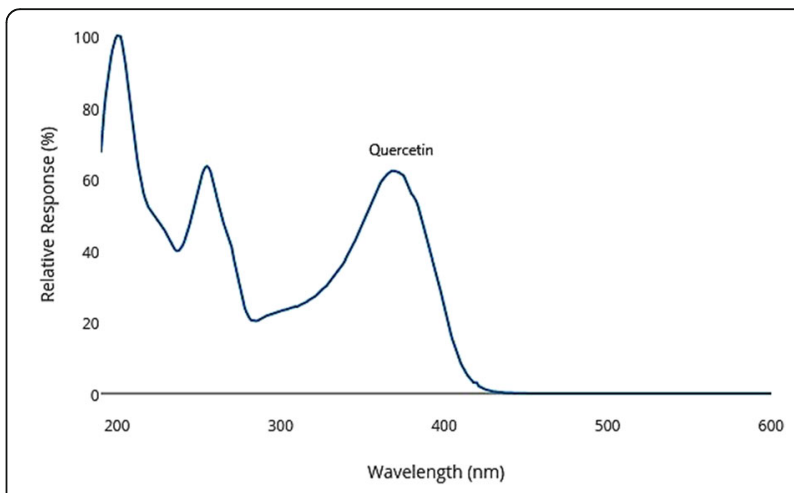

Fig. 5 Overlay UV absorption spectra of quercetin in peaks of standard and extracts 

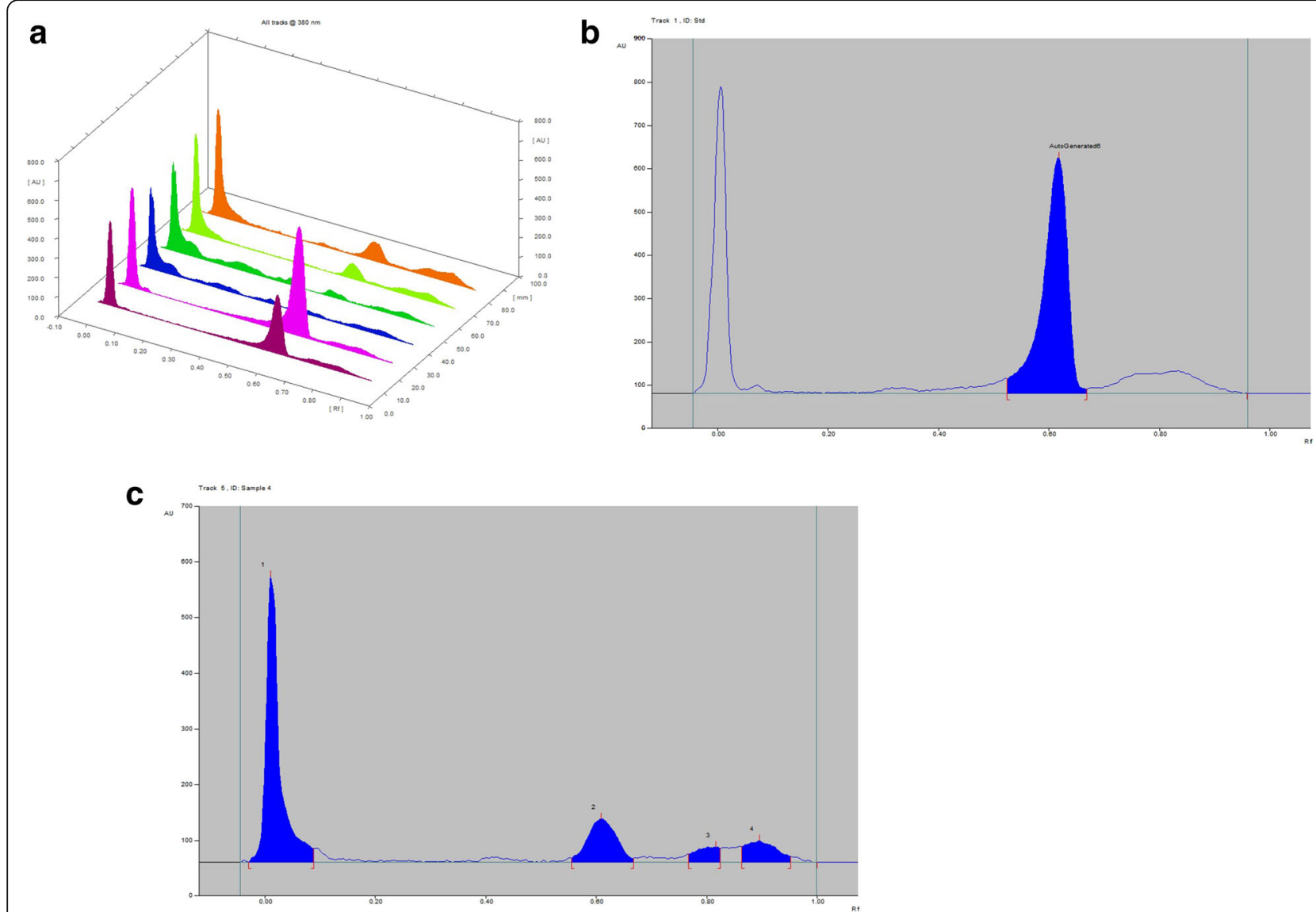

Fig. 6 HPTLC chromatogram of leaf extract with quercetin (a) 3D display of leaf extract with quercetin chromatogram, (b) HPTLC densitogram and chromatogram of standard quercetin and (c) leaf extract at $380 \mathrm{~nm}$

\section{Acute oral toxicity}

Acute oral toxicity was carried out by up- and downregulation method. There were no signs of toxicity or deaths observed in mice treated by a single oral administration of the both leaves extract of $A$. ficulneus L. at limit dose $2000 \mathrm{mg} / \mathrm{kg}$ p.o. $1 / 10^{\text {th }}$ of this dose, i.e. 200 $\mathrm{mg} / \mathrm{kg}$ for AEAF and EEAF were used in the subsequent study respectively.

\section{Haemagglutinating antibody titre}

The HA titre mainly manifest to asses primary and secondary humoral immune responses. Specific primary and secondary HA titre values in SRBCs control group, AEAF, EEAF and Levamisole groups was significantly $(p<0.001)$ increased when compared to normal control groups (Table 7 and Fig. 8). This shows the increased production of HA titre against SRBCs as antigen in AEAF and EEAF
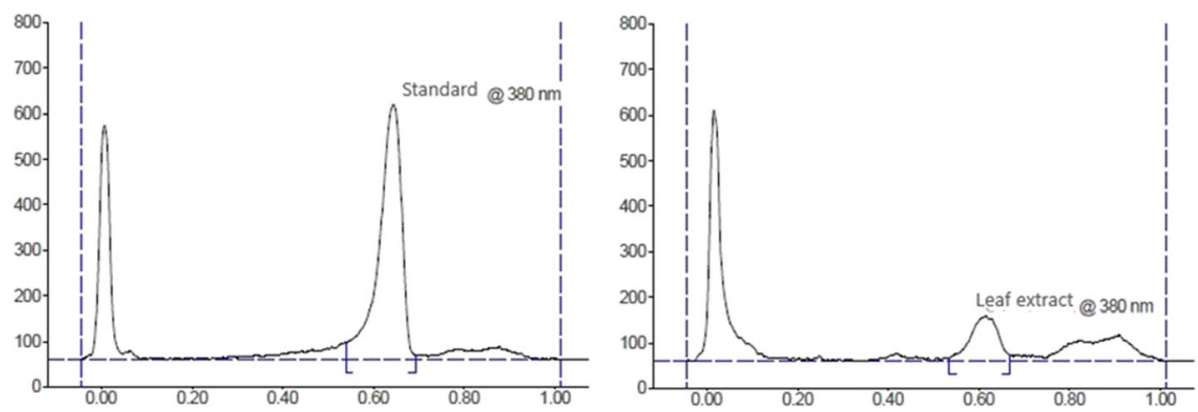

Fig. 7 HPTLC Densitogram of Standard (quercetin) and leaf extract Rf values are 0.64 and 0.62 at $380 \mathrm{~nm}$ respectively 
Table 7 Effect of aqueous and ethanolic extract of A. ficulneus L. leaves on specific primary and secondary antibody response in mice

\begin{tabular}{llll}
\hline Groups $(\boldsymbol{n}=\mathbf{6})$ & Treatment & $\begin{array}{l}\text { Primary HA titre } \\
\text { Mean } \pm \text { SEM }\end{array}$ & $\begin{array}{l}\text { Secondary HA titre } \\
\text { Mean } \pm \text { SEM }\end{array}$ \\
\hline Negative control & Cyp. $100 \mathrm{mg} / \mathrm{kg}$, p.o. & $1.167 \pm 0.1667$ & $1.667 \pm 0.2108$ \\
Vehicle control & Distilled water, $10 \mathrm{ml} / \mathrm{kg}$, (p.o.) & $2.333 \pm 0.2108^{\#}$ & $3.000 \pm 0.3651^{\#}$ \\
AEAF & $200 \mathrm{mg} / \mathrm{kg} \mathrm{p.o.}$ & $4.667 \pm 0.2108^{* * *}$ & $6.500 \pm 0.2236^{* * *}$ \\
EEAF & $200 \mathrm{mg} / \mathrm{kg} \mathrm{p.o.}$ & $4.833 \pm 0.3073^{* * *}$ & $7.500 \pm 0.2236^{* * *}$ \\
Levamisole & LMS $50 \mathrm{mg} / \mathrm{kg}$, p.o. & $5.000 \pm 0.2582^{* * *}$ & $8.333 \pm 0.3333^{* * *}$ \\
AEAF + Cyp. & $200 \mathrm{mg} / \mathrm{kg} \mathrm{p.o.} \mathrm{+} \mathrm{single} \mathrm{dose} \mathrm{of} \mathrm{Cyp.100} \mathrm{mg/kg,} \mathrm{p.o.}$ & $4.500 \pm 0.2236^{* * *}$ & $6.167 \pm 0.3073^{* * *}$ \\
EEAF + Cyp. & $200 \mathrm{mg} / \mathrm{kg} \mathrm{p.o.} \mathrm{+} \mathrm{single} \mathrm{dose} \mathrm{of} \mathrm{Cyp.100} \mathrm{mg/kg,} \mathrm{p.o.}$ & $6.667 \pm 0.2108^{* * *}$ & $8.000 \pm 0.3651^{* * *}$ \\
LMS + Cyp. & LMS $(50 \mathrm{mg} / \mathrm{kg}$, p.o. $)+$ single dose of Cyp. $100 \mathrm{mg} / \mathrm{kg}$, p.o. & $7.833 \pm 0.3073^{* * *}$ & $8.500 \pm 0.3416^{* * *}$ \\
\hline
\end{tabular}

mice groups. Whereas in cyclophosphamide + SRBCstreated group, HA titre was significantly showing a dosedependent increase action $(p<0.001)$ compared to SRBCs-treated group. The effect is due to immunosuppression by cyclophosphamide which abruptly decreases the level of HA in blood. Results indicate that protection of AEAF and EEAF toward immunosuppression by cyclophosphamide through increased significant level HA titre in the blood (Fig. 9).

\section{Delayed type hypersensitivity}

The DTH response measured by footpad thickness in the hind paw is an indicator of cell-mediated immunity. The percentage change in DTH response found after $24 \mathrm{~h}$ in the AEAF EEAF and Levamisole groups was $33.20 .49 \pm 0.062,63.80 .74 \pm 0.033$ and $0.84 \pm 0.021$ respectively. It was $0.72 \pm 0.028,0.73 \pm 0.030$ and $0.81 \pm 0.021$ in the Cyp-treated groups compared to control animals (Table 8 and Fig. 10). EEAF significantly $(p<0.01)$ stimulated the cell-mediated immune response. Thus, Cyclophosphamide is responsible for inhibition of cellular immune response. Results show AEAF and EEAF $200 \mathrm{mg} / \mathrm{kg}$ in the presence of

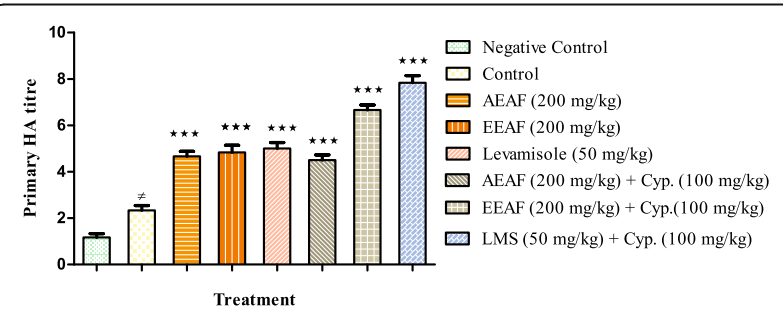

Fig. 8 Effect of AEAF and EEAF on Primary HA titre. Results were expressed as mean $\pm \operatorname{SEM},(n=6)$. Statistical analysis was performed with one-way analysis of variance (ANOVA) followed by TukeyKramer multiple comparison test. \#P<0.05, \#\#P<0.01 as compared with NC. $P$ value less than $<0.05$ was considered to be statistically significant. ${ }^{*} P<0.05,{ }^{*} P<0.01$ and ${ }^{* * *} P<0.001$, when compared with control
Cyclophosphamide showed significant $(p<0.001)$ increase in footpad reaction when compared with the alone Cyclophosphamide-treated control group. Therefore, treatment with AEAF and EEAF in the presence of immunosuppressant like Cyclophosphamide is capable of stimulating cellular immune response.

\section{Neutrophil adhesion test}

Blood is incubated with nylon fibres (NF) and is responsible to decrease in the neutrophil counts due to adhesion of neutrophils to the fibres. Doses of AEAF and EEAF showed significant increase $(p<0.05)$ in the neutrophil adhesion when compared to control (Table 9 and Fig. 11)

\section{Carbon clearance test}

Administration of AEAF (200 mg/kg, p.o.) and EEAF (200 mg/kg, p.o.) shows increased in the withdrawal of carbon particles through blood is indicated by a significant increase in phagocytic index $(p<0.05)$ when compared with control group (Table 10 and Fig. 12).

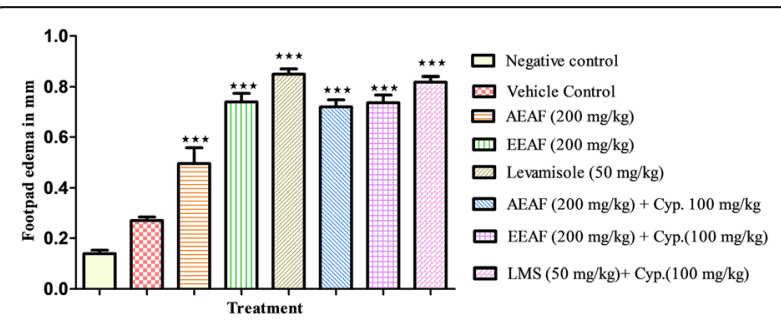

Fig. 9 Effect of AEAF and EEAF on Secondary HA titre. Results were expressed as mean $\pm \mathrm{SEM},(n=6)$. Statistical analysis was performed with one-way analysis of variance (ANOVA) followed by TukeyKramer multiple comparison test. \#P<0.05, \#\#P<0.01 as compared with NC. $P$ value less than $<0.05$ was considered to be statistically significant. ${ }^{*} P<0.05,{ }^{* *} P<0.01$ and ${ }^{* *} P<0.001$, when compared with control 
Table 8 Effect of aqueous and ethanolic extract of A. ficulneus L. leaves on delayed type of hypersensitivity (DTH) in mice

\begin{tabular}{lll}
\hline Groups $(\boldsymbol{n}=\mathbf{6})$ & Treatment & $\begin{array}{l}\text { DTH } \\
\text { Mean diff. of paw oedema in (mm) } \\
\text { Mean } \pm \text { SEM }\end{array}$ \\
\hline Negative control & Cyp.100 mg/kg, p.o. & $0.13 \pm 0.014$ \\
Vehicle control & Distilled water, $10 \mathrm{ml} / \mathrm{kg}$, p.o. & $0.27 \pm 0.014^{\#}$ \\
AEAF & $200 \mathrm{mg} / \mathrm{kg}$, p.o. & $0.49 \pm 0.062^{* * *}$ \\
EEAF & $200 \mathrm{mg} / \mathrm{kg}$, p.o. & $0.74 \pm 0.033^{* * *}$ \\
Levamisole & LMS $50 \mathrm{mg} / \mathrm{kg}$, p.o. & $0.84 \pm 0.021^{* * *}$ \\
AEAF + Cyp. & $200 \mathrm{mg} / \mathrm{kg} \mathrm{p.o.}+$ single dose of Cyp.100 mg $/ \mathrm{kg}$, p.o. & $0.72 \pm 0.028^{* * *}$ \\
EEAF + Cyp. & $200 \mathrm{mg} / \mathrm{kg} \mathrm{p.o.}+$ single dose of Cyp.100 mg/kg, p.o. & $0.73 \pm 0.030^{* * *}$ \\
LMS + Cyp. & LMS $(50 \mathrm{mg} / \mathrm{kg}$, p.o. $)+$ single dose of Cyp.100 mg/kg, p.o. & $0.81 \pm 0.021^{* * *}$
\end{tabular}

\section{Mice lethality test}

One hundred percent mortality was found in negative control group within $72 \mathrm{~h}$ by administration of Pasteurella multocida. There was $66.66 \%$ and $50 \%$ mortality in AEAF and EEAF vaccinated group and 50\% mortality found in vehicle control group, whereas in standard group (levamisole), 33.33\% mortality was found as compared to negative control group shown in Table 11. The results suggest that AEAF is most effective amongst treatments with test materials in preventing mortality.

\section{Discussion}

Modulation of the immune system by plant origin isolated extracts and fractions is an emerging field in scientific literature studies, especially in cases where unwanted immunosuppression is the result of various therapy [24]. Plant extracts have been widely investigated in the recent time in different parts of the world for their possible immunomodulatory properties [25].

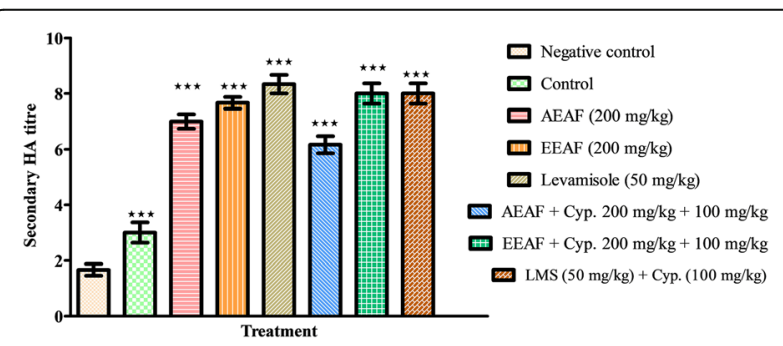

Fig. 10 Effect of AEAF and EEAF on delayed type of hypersensitivity $(D T H)$ in mice. Results were expressed as mean \pm SEM, $(n=6)$. Statistical analysis was performed with one-way analysis of variance (ANOVA) followed by Tukey-Kramer multiple comparison test. \#P< 0.05, \#\#P $<0.01$ as compared with NC. $P$ value less than $<0.05$ was considered to be statistically significant. ${ }^{*} P<0.05$, ${ }^{* *} P<0.01$ and ${ }^{* *} P<0.001$, when compared with control
Immunomodulatory effect of $A$. ficulneus L. leaves extracts were evaluated on two types of immune system at humoral and cellular level immune response on haemagglutinating titre, DTH response, phagocytic function, neutrophil adhesion response, mouse lethality effect and cyclophosphamide-induced myelosuppression in mice. Proposed findings show that both leaves extracts possesses immunostimulatory effect in experimental animal models of cellular and humoral immunity.

The preliminary phytochemical analysis, flavonoid, phenolic content and TLC studies of $A$. ficulneus L. revealed the presence of saponin glycosides, steroids, tannins, flavonoids and phenolic compounds.

The result of the acute oral toxicity showed that both extracts have a wide safety margin. This is an indication that both extracts are nontoxic and safe at effective doses that prevent lethal effects.

In the present study, HPTLC method was developed for quercetin in leaves extracts of $A$. ficulneus $\mathrm{L}$. The developed method was simple, accurate and specific for the analysis of quercetin in herbal crude drug sample. Results indicate that leaves extract of $A$. ficulneus $\mathrm{L}$. is a rich source of quercetin and may be more useful for formulations.

The stimulation of the humoral response by both the leaves extracts as evidenced by an enhancement of

Table 9 Effect of aqueous and ethanolic extract of A. ficulneus $\mathrm{L}$. leaves on neutrophil adhesion in mice

\begin{tabular}{lll}
\hline $\begin{array}{l}\text { Groups } \\
(\boldsymbol{n}=\mathbf{6})\end{array}$ & Treatment & $\begin{array}{l}\text { Neutrophil adhesion (\%) } \\
\text { Mean } \pm \text { SEM }\end{array}$ \\
\hline $\begin{array}{l}\text { Vehicle } \\
\text { control }\end{array}$ & $\begin{array}{l}\text { Distilled water, } 10 \mathrm{ml} / \mathrm{kg}, \\
\text { p.o. }\end{array}$ & $25.50 \pm 0.76$ \\
AEAF & $200 \mathrm{mg} / \mathrm{kg}$, p.o. & $37.00 \pm 0.57^{* * *}$ \\
EEAF & $200 \mathrm{mg} / \mathrm{kg}$, p.o. & $38.00 \pm 0.57^{* * *}$ \\
Levamisole & LMS $50 \mathrm{mg} / \mathrm{kg}$, p.o. & $42.83 \pm 0.70^{* * *}$ \\
\hline
\end{tabular}




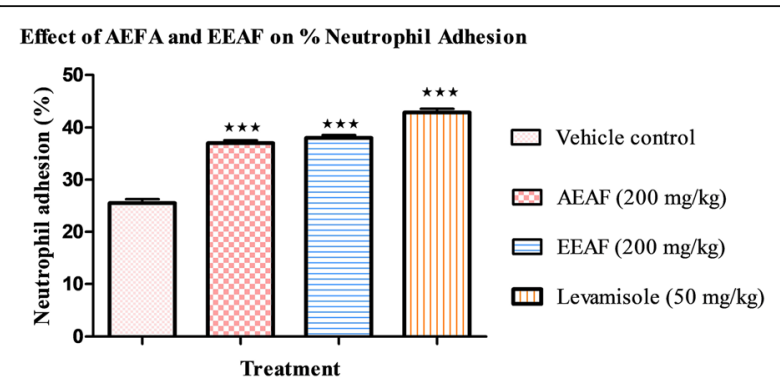

Fig. 11 Effect of AEAF and EEAF on Neutrophil adhesion test in mice. Results were expressed as mean $\pm \operatorname{SEM},(n=6)$. Statistical analysis was performed with one-way analysis of variance (ANOVA) followed by Dunnett's multiple comparison test. \#P $<0.05$, \#\#P $<0.01$ as compared with NC. $P$ value less than $<0.05$ was considered to be statistically significant. ${ }^{*} P<0.05$, ${ }^{*} P<0.01$ and ${ }^{* *} P<0.001$, when compared with control

antibody titre using antigen SRBCs in mice indicates the enhanced excitability of macrophages and B lymphocyte subsets involved in antibody formation [18].

The delayed hypersensitivity response directly correlated with enhancement in $\mathrm{T}$ lymphocytes. The increased response indicates that $A$. ficulneus $\mathrm{L}$. leaves extracts have a stimulating effect on $B$ lymphocytes and macrophages killing activity through nitric oxide release by stimulating $\mathrm{T}$ cell for the hypersensitivity reaction on cellular mediated immunity [26].

A. ficulneus L. leaves extracts show significantly increased adhesion of neutrophils to nylon fibers which correlate with the process of margination of cells in blood vessels. This might be due to the hyperactivation of the $\beta 2$ integrins, present on the membrane of the neutrophil through which they adhere firmly to the nylon fibers. Hence, it was concluded that A. ficulneus L. leaves extracts caused stimulation of neutrophil towards the site of inflammation [26].

The rate of carbon clearance is the identified ability of the reticuloendothelial system and its granulopoiesis activity. The faster removal of carbon particles has been correlated with the enhanced phagocytic activity [27].

Table 10 Effect of aqueous and ethanolic extract of A. ficulneus $\mathrm{L}$. leaves on carbon clearance test in mice

\begin{tabular}{lll}
\hline Groups $(\boldsymbol{n}=6)$ & Treatment & $\begin{array}{l}\text { Phagocytic Index } \\
\text { Mean } \pm \text { SEM }\end{array}$ \\
\hline Vehicle control & Distilled water, $10 \mathrm{ml} / \mathrm{kg}$, p.o. & $0.018 \pm 0.0030$ \\
AEAF & $200 \mathrm{mg} / \mathrm{kg}$, p.o. & $0.045 \pm 0.0042^{* * *}$ \\
EEAF & $200 \mathrm{mg} / \mathrm{kg}$, p.o. & $0.050 \pm 0.0036^{* * *}$ \\
Levamisole & LMS $50 \mathrm{mg} / \mathrm{kg}$, p.o. & $0.056 \pm 0.0049^{* * *}$ \\
\hline
\end{tabular}

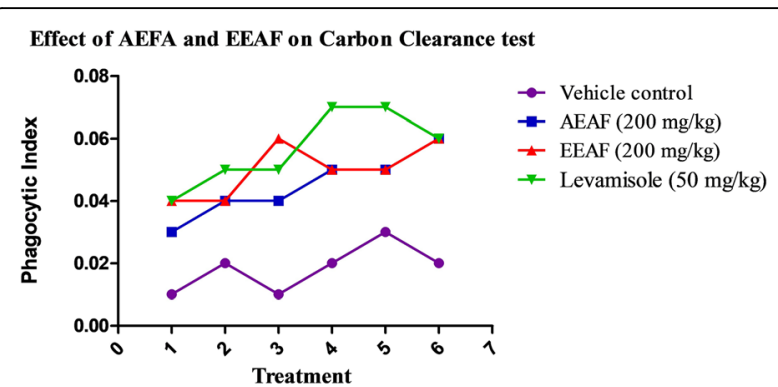

Fig. 12 Effect of AEAF and EEAF on Carbon Clearance test in mice. Results were expressed as mean $\pm \operatorname{SEM},(n=6)$. Statistical analysis was performed with one-way analysis of variance (ANOVA) followed by Dunnett's multiple comparison test

Commonly used method for assessment of serological response is mice lethality test in mice immunized with vaccines. In this test, mice were injected with the vaccine before administration of the bacterial culture; Pasteurella multocida is pathogenic to rodents and determines the mortality percentage. A. ficulneus L. decreases the rate of mortality by stimulating antibodies that can counter the pathogen [28].

Findings of the present study showed an overall stimulatory effect of $A$. ficulneus L. on specific (humoral immune response), cellular (cell mediated immune response) and nonspecific immunity.

\section{Conclusion}

A. ficulneus L. leaves extract at $200 \mathrm{mg} / \mathrm{kg}$ doses potentiate immune system by specific humoral and cellular immunity mechanism in different experimental animal models. Further pharmacological screening of each isolated compound of extracts to be evaluated for its immunomodulatory activity and probable mechanism of action to be explored.

Table 11 Effect of aqueous and ethanolic extract of A. ficulneus L. leaves on Mice lethality rate in mice

\begin{tabular}{|c|c|c|c|c|c|}
\hline \multirow{2}{*}{$\begin{array}{l}\text { Groups } \\
(n=6)\end{array}$} & \multirow[t]{2}{*}{ Treatment } & \multicolumn{4}{|c|}{ Mortality Percentage } \\
\hline & & Day 1 & Day 2 & Day 3 & Day 4 \\
\hline $\begin{array}{l}\text { Negative } \\
\text { Control }\end{array}$ & $\begin{array}{l}\text { No drug, no } \\
\text { vaccination }\end{array}$ & Nil & $50 \%$ & $50 \%$ & $100 \%$ \\
\hline $\begin{array}{l}\text { Vehicle } \\
\text { control }\end{array}$ & $\begin{array}{l}\text { Distilled water, } \\
10 \mathrm{ml} / \mathrm{kg}, \text { p.o.+ } \\
\text { vaccination }\end{array}$ & Nil & $16.66 \%$ & $33.33 \%$ & $50 \%$ \\
\hline AEAF & $\begin{array}{l}200 \mathrm{mg} / \mathrm{kg}, \\
\text { p.o. + vaccination }\end{array}$ & Nil & $16.66 \%$ & $50 \%$ & $66.66 \%$ \\
\hline EEAF & $\begin{array}{l}200 \mathrm{mg} / \mathrm{kg}, \\
\text { p.o. + vaccination }\end{array}$ & Nil & $16.66 \%$ & $33.33 \%$ & $50 \%$ \\
\hline Levamisole & $\begin{array}{l}\text { LMS } 50 \text { mg / kg, } \\
\text { p.o. + vaccination }\end{array}$ & Nil & $16.66 \%$ & $16.66 \%$ & $33.33 \%$ \\
\hline
\end{tabular}




\section{Abbreviations}

SRBCs: Sheep red blood cells; HA: Haemagglutinating titre; DTH: Delayed type hypersensitivity; IAEC: Institutional Animal Ethical Committee; LOD: Limit of detection; LOQ: Limit of quantization; AEAF: Aqueous extract of $A$. ficulneus L.; EEAF: Ethanolic extract of A. ficulneus L; CYP: Cyclophosphamide; LMS: Levamisole

\section{Acknowledgements}

Authors thankful to PES, Modern college of pharmacy and METs, Institute of Pharmacy forproviding the facilities to conduct this research work.

\section{Plant authentication}

A. ficulneus (L.) herb was collected and procured in the month of July and leaves were dried in the shade. The A. ficulneus (L.) was authenticated by an herbarium section of a botanical survey of India, Maharashtra, Pune. No. BSI/ WRC/Cert./2014

\section{Authors' contributions}

ND drafted the work, revised it and analysed the results. DB designed the study and done substantial contribution in analysis of the data. ND made substantial contribution in acquisition of raw material and revision of the study. Both the authors have read and approved the manuscript.

\section{Funding}

Proposed work not funded by any funding agencies.

\section{Availability of data and materials}

All data and material are available on request.

\section{Declarations}

Ethics approval and consent to participate

The experimental animal protocol approved by the Institutional Animal Ethical Committee (IAEC) and care of animals was taken as per guidelines of CPCSEA, Department of Animal Welfare, and Government of India. (Protocol No.: 884/PO/Re/S/05/CPCSEA).

\section{Consent for publication}

Not applicable.

\section{Competing interests}

The authors declare that they have no competing interests.

\section{Author details}

'Department of Pharmacology, PES's, Modern College of Pharmacy, Affiliated to Savitribai Phule Pune University, Yamunanagar, Nigdi, Pune, Maharashtra 411044, India. ${ }^{2}$ Department of Pharmacology, METs, Institute of Pharmacy, Bhujbal Knowledge City, Adgaon, Nashik, Maharashtra 422003, India. ${ }^{3}$ Department of Pharmacology, PES's, Modern College of Pharmacy, Affiliated to Savitribai Phule Pune University, Yamunanagar, Nigdi, Pune, Maharashtra 411044, India.

Received: 28 January 2021 Accepted: 10 May 2021

Published online: 23 July 2021

\section{References}

1. Thamizhselvam N, Gk S (2020) Medicinal plants in Rasayana drugs, their active ingredients and reported biological activities : an overview, pp 1-5

2. Venugopalan SN (2017) Understanding the concepts Rasayana in Ayurveda biology. J Nat Ayurvedic Med 1(2). https://doi.org/10.23880/jonam-16000112

3. Ganeshpurkar A, Saluja AK (2017) Experimental animal models used for evaluation of potential immunomodulators: a mini review. Bull Fac Pharmacy, Cairo Univ 55(2):211-216. https://doi.org/10.1016/j.bfopcu.2017. 08.002

4. Peluso I, Miglio C, Morabito G, loannone F, Serafini M (2015) Flavonoids and immune function in human: a systematic review. Crit Rev Food Sci Nutr 55(3):383-395. https://doi.org/10.1080/10408398.2012.656770

5. Guptha A (2016) Immunopharmacological studies of medicinal plants. J Clin Exp Immunol 01:1-2
6. Mohite AV, Gurav RV (2019) Nutraceutical and antioxidant evaluation of Abelmoschus taxa. Int J Veg Sci 25(6):610-618. https://doi.org/10.1080/1931 5260.2019 .1597801

7. Florence PS (2019) Chapter V. Use fact stat Investig Ind fatique, pp 56-60

8. Khandelwal KR (2008) Practical pharmacognosy. Pragati Books Pvt. Ltd

9. Trease GEEW (1983) In: Balliere (ed) Textbook of Pharmacognosy. Tindall, London

10. Kokate CK, Purohit APGS (2001) Pharmacognosy by CK kokate Nirali Prakashan

11. Kamali H, Khodaverdi E, Hadizadeh F, Ghaziaskar SH (2016) Optimization of phenolic and flavonoid content and antioxidants capacity of pressurized liquid extraction from Dracocephalum kotschyi via circumscribed centra composite. J Supercrit Fluids 107:307-314. https://doi.org/10.1016/j.supflu.2 015.09.028

12. Bitis L, Sen A, Ozsoy N, Birteksoz-Tan S, Kultur S, Melikoglu G (2017) Flavonoids and biological activities of various extracts from Rosa sempervirens leaves. Biotechnol Biotechnol Equip 31(2):299-303. https://doi. org/10.1080/13102818.2016.1277956

13. Alara OR, Abdurahman NH, Ukaegbu Cl, Kabbashi NA (2019) Extraction and characterization of bioactive compounds in Vernonia amygdalina leaf ethanolic extract comparing Soxhlet and microwave-assisted extraction techniques. J Taibah Univ Sci 13(1):414-422. https://doi.org/10.1080/16583 655.2019.1582460

14. Sharif S, Kitaz A, Al-Kayali R (2016) TLC screening and evaluation of antioxidant, antibacterial activity of Onopordon macrocephalum by bioautography method. Iran J Pharm Sci 12:1-8

15. Wagner HBS (1996) Plant drug analysis: a thin layer chromatography atlas. Springer Science \& Business Media. https://doi.org/10.1007/978-3-642-00574-9

16. Abhimanyu KK, Ravindra CS, Avanapu RS (2017) A validated HPTLC method for the quantification of friedelin in Putranjiva roxburghii wall extracts and in polyherbal formulations. Bull Fac Pharmacy, Cairo Univ 55(1):79-84. https://doi.org/10.1016/j.bfopcu.2016.11.002

17. OECD 420 (2001) Test guideline 425: acute oral toxicity-Fixed Dose Procedure. Guidel Test Chem 26:1-14

18. Mungantiwar AA, Nair AM, Shinde UA, Dikshit VJ, Saraf MN, Thakur VS, Sainis KB (1999) Studies on the immunomodulatory effects of Boerhaavia diffusa alkaloidal fraction. J Ethnopharmacol 65(2):125-131. https://doi.org/10.1016/ S0378-8741(98)00153-6

19. Mubashir K, Ghazanfar K, Ganai BA, Akbar S, Malik AH, Masood A (2014) Scientific validation of Gentiana kurroo royle for anti-inflammatory and immunomodulatory potential. ISRN Inflamm 2014:1-5. https://doi.org/10.1155/2014/701765

20. Thakur M, Bhargava S, Dixit VK (2007) Immunomodulatory activity of Chlorophytum borivilianum Sant. F. Evid-based Complement Altern Med 4(4):419-423. https://doi.org/10.1093/ecam/nel094

21. Pravansha S, Thippeswamy BS, Veerapur VP (2012) Immunomodulatory and antioxidant effect of Leptadenia reticulata leaf extract in rodents: possible modulation of cell and humoral immune response. Immunopharmacol Immunotoxicol 34(6):1010-1019. https://doi.org/10.3109/08923973.2012.689767

22. Shabbir A, Arshad HM, Shahzad M, Shamsi S, Ashraf MI (2016) Immunomodulatory activity of mefenamic acid in mice models of cellmediated and humoral immunity. Indian J Pharm 48(2):172-178. https://doi. org/10.4103/0253-7613.178837

23. Savita K, Prakashchandra K (2011) Optimization of extraction conditions and development of a sensitive HPTLC method for estimation of wedelolactone in different extracts of Eclipta alba. Int J Pharm Sci Drug Res 3:56-61

24. Naved T, Siddiqui II, Ansari SH, Ansari AA, Mukhtar HM (2005) Immunomodulatory activity of Mangifera indica L. fruits (cv Neelam). J Nat Remedies 5:137-140

25. Eze Jl, Ekelozie CF, Nweze NE (2017) Immunomodulatory activity of buchholzia coriacea seed methanol extract on trypanosoma brucei brucei infected mice Pharm Biol 55(1):636-640. https://doi.org/10.1080/13880209.2016.1265988

26. Pandey P, Mehta A, Hajra S (2016) Evaluation of the immunomodulatory activity of the alcoholic extracts of ruta graveolens leaves. Int J Pharm Pharm Sci 8(11):332-336. https://doi.org/10.22159/ijpps.2016v8i11.15531

27. Kanamarlapudi Vijayabhargava MA (2011) Effect of stigmas of Crocus sativus L. (saffron) on cell mediated and humoral immunity. Nat Prod J 1:151-155

28. Patel P, Asdaq SMB (2010) Immunomodulatory activity of methanolic fruit extract of Aegle marmelos in experimental animals. Saudi Pharm J 18(3): 161-165. https://doi.org/10.1016/j.jsps.2010.05.006

\section{Publisher's Note}

Springer Nature remains neutral with regard to jurisdictional claims in published maps and institutional affiliations. 